ZOOLOGIA 30 (1): 97-100, February, 2013

http://dx.doi.org/10.1590/S1984-46702013000100012

\title{
A new species of Anna (Mollusca: Neogastropoda: Buccinidae) from Brazil
}

\author{
José Coltro ${ }^{1} \&$ Ana Paula S. Dornellas ${ }^{2}$
}

${ }^{1}$ Caixa Posta 15011,01599-970 São Paulo, SP, Brazil. E-mail: jose@femorale.com

2 Museu de Zoologia, Universidade de São Paulo. Caixa Postal 42494, 04218-970 São Paulo, SP, Brazil.

E-mail: dornellas.anapaula@usp.br

\begin{abstract}
Anna capixaba, a new species found in depths of $45-60 \mathrm{~m}$ off the coast of the state of Espírito Santo, southeastern Brazil, is herein described. The new species is mainly characterized by a teleoconch of 4.5 whorls, weakly demarcated from the protoconch; sculptured by rounded, prominent, narrowly-separated, spiral threads; outer lip with 5-6 teeth, posterior tooth stronger; columella with two plicae, smooth.
\end{abstract}

KEY WORDS. Continental shelf; new species; taxonomy; western Atlantic.

Buccinidae Rafinesque, 1815 is a large family of Caenogastropoda with species distributed worldwide. Currently, there are more than 200 genera and subgenera included in this family, with species that inhabit a very wide variety of marine environments (HaYashi 2005, Kos'Yan \& Kantor 2007).

Anna Risso, 1826 (Type species: Anna Massena Risso, 1826, by monotypy) is a genus of marine predatory animals, known and originally described from the Mediterranean Sea and the Canary Islands (GARCía 2008). Four species are also distributed from Florida to the Caribbean Sea (WATTERs 2009). Recently, some specimens of Anna were found off the coast of the state of Espírito Santo, Brazil, in residues of bryozoan and dead corals trawled by lobster nets. According to WatTers (2009), Anna is most similar to Parviphos Sarasua, 1984, from which it differs mainly in having a round protoconch and a massive terminal varix that does not project far out from the whorl, or is reflected backward at the same level of the whorl.

\section{MATERIAL AND METHODS}

Samples were obtained from lobster nets trawled at 45$60 \mathrm{~m}$. Only empty shells were found, but in a good state of preservation. In order to illustrate the protoconch, we used multifocus photography. Shell length was measured from the tip of the apex to the end of the siphonal canal, and shell width was measured as the maximum dimension in a plane with the aperture perpendicular to the coiling axis. Abbreviations: (MZSP) Museu de Zoologia da Universidade de São Paulo, Brazil; (GSPH) Steve Hubrech collection, Hervelle, Belgium; (MNHN) Muséum national d'Histoire naturelle, Paris.

\section{TAXONOMY}

\section{Anna capixaba sp. nov.}

Figs $1-6,9-10$

Type Material. Holotype: Brazil, Espírito Santo: off Conceição da Barra (18 $\left.36^{\prime} \mathrm{S} 39^{\circ} 32^{\prime} \mathrm{W}, 40-50 \mathrm{~m}\right)$, December 2009, J. Coltro leg., MZSP 101385. Paratypes: from type locality, 1 shell, MZSP 101386. Off Guarapari (70-80 m), 1 shell, April 2012, J. Coltro leg., MNHN IM-2012-1.

Type Locality. Brazil, state of Espírito Santo, off Conceição da Barra (18³6'S 39³2’ W, 40-50 m).

Description. Shell fusiform; elongated, about twice longer than wide; holotype $11.8 \mathrm{~mm}$ long. Protoconch (Figs 9-10) mammilate of 1.5-2 whorls of 0.3-0.4 mm; smooth; whitish whorls with tan blotches at the apex. Teleoconch of 4.5 whorls slightly concave, well demarcated from protoconch by growth scar and change in ornamentation. Teleoconch sculpture of about 15 rounded, prominent, narrowly-separated, spiral threads. Spiral cords on siphonal canal slightly weaker. Axial sculptured of widely-separated, rounded, high ribs; ribs almost as wide as interspaces; about nine ribs on last whorl, not including varix. Intersections of axial and spiral sculptured with elongated nodules formed from cords; about nine nodules on last whorl. Terminal varix welldeveloped, somewhat constricted, wide; inner-side with 5-6 teeth, posterior tooth stronger. Aperture oval, about 50\% of total length; outer lip thin, crenulated, with about seven short very slightly lirae equidistant from each other on the inner side; posterior canal delimited by two tooth-like projections at outer lip and on parietal 


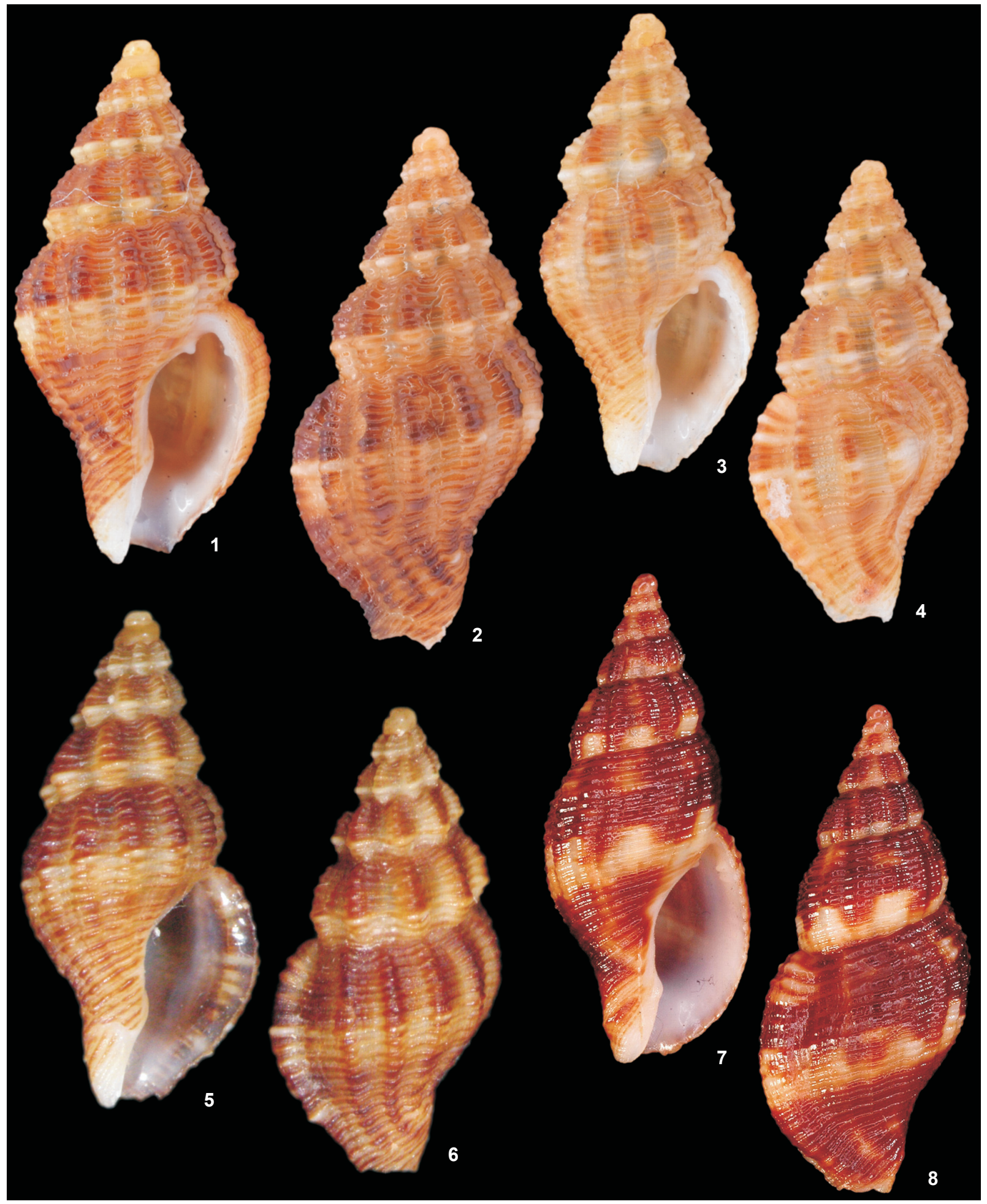

Figures1-8. Anna capixaba sp. nov. and Dianthiphos bernardoi shells in apertural and dorsal views. (1-6) Anna capixaba sp.nov.: (1-2) holotype MZSP 101385, $11.8 \mathrm{~mm}$ in length; (3-4) paratype MZSP 101386, $11 \mathrm{~mm}$ in length; (5-6) paratype MNHN IM-2012-1, 11.1 mm in length; (7-8) Dianthiphos bernardoi: paratype MZSP 28196, 13.7mm in length. 

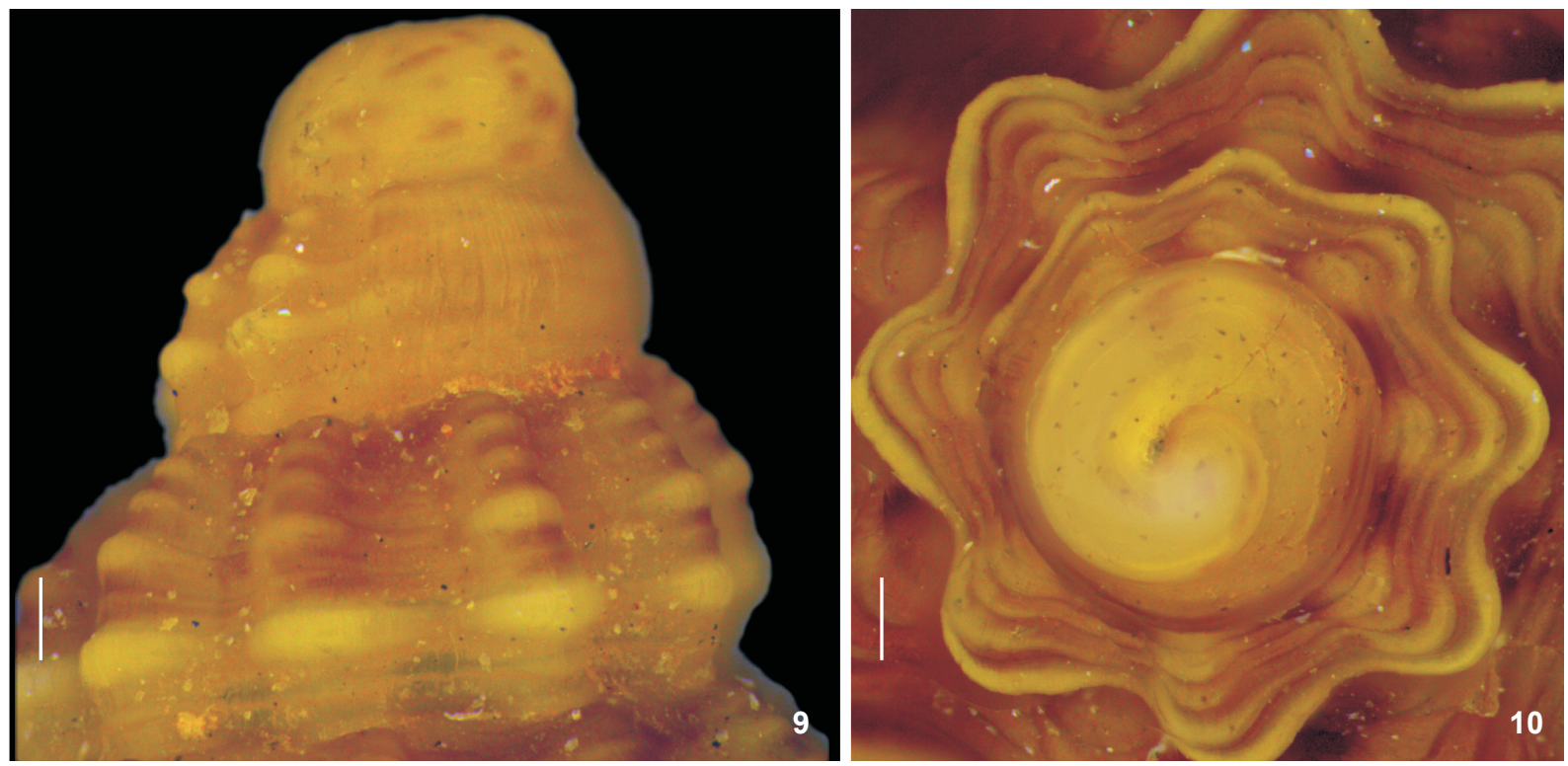

Figures 9-10. Protoconch of Anna capixaba sp. nov.: (9) apertural view, holotype MZSP 101385; (10) apical view, paratype MNHN IM-2012-1. Scales bars $=0.2 \mathrm{~mm}$.

wall. Columella angled at siphonal canal, bounded by two plications; smooth. Siphonal canal short, open. Color from dark brown to caramel-brown, with a pale yellowish-cream band on lower central body; aperture white-cream. Operculum, radula and anatomy unknown.

Measurements (length by width, in mm). Holotype. MZSP 101385, 11.8 by 5.7; Paratypes. MZSP 101386, 11 by 5.5; MNHN IM-2012-1, 11.1 by 5.4 .

Material examined. Anna capixaba sp. nov. types and 1 shell are deposited in the GSPH collection. Dianthiphos bernardoi Costa \& Gomes, 1998 MZSP 28196, paratype, 1 specimen, Brazil, Espírito Santo, Guarapari; MZSP 91058, 09 specimens, same locality; MZSP 91061, 14 specimens, same locality.

Distribution. Known so far only from the coast of Espírito Santo: Conceição da Barra and Guarapari.

Habitat. Lives probably on bryozoan and coral bottoms, at $45-60 \mathrm{~m}$.

Etymology. The specific epithet is the demonym for the people of Espírito Santo and is an arbitrary combination of letters.

\section{DISCUSSION}

In a revision of the western Atlantic Buccinids, WATTERS (2009) remarked that the four congeneric species occurring from Florida to the Caribbean Sea, namely Anna florida García, 2006; A. milleri (Usticke, 1959); A. royalensis Watters, 2009 and $A$. willemsae (De Jong \& Coomans, 1988) differ slightly from the eastern Atlantic species of Anna by having fewer axial ribs on the last whorl (seven to thirteen) and by having lirae instead of denticles on the inner side of the outer lip (VermeIJ 2006, LANDAU \& VERMEI 2012), and could therefore be placed together in a new genus

Anna capixaba sp. nov. differs from other western Atlantic congenerics by having a much stronger posterior tooth on the outer lip, a smooth columella, and inconspicuous lirae, which are almost imperceptible on the inner side of the outer lip. A related species from the West African coast (also in a few places in the Canaries) (Pope \& Goto 1991), Anna assimilis (Reeve, 1846), differs from A. capixaba sp. nov. in having a heavily dark axial band between the ribs. This band is not present in A. capixaba sp. nov.; another difference is in the sculpture: A. capixaba sp. nov. has more delicate lirae on the inner side of the outer lip, and weaker axial ribs. Both species seem to be closely related, but the particularities of each species make the possibility of an accidental introduction of $A$. assimilis in the Central South Brazilian coast unlikely. Moreover, $A$. assimilis also shares the characteristics mentioned only for Anna species in the western Atlantic, and therefore the distribution about Anna is not geographically restricted to the western Atlantic as previously mentioned (WatTers 2009, LANDAU \& VERMEIJ 2012).

Within the western Atlantic fauna, Anna is most similar to Parviphos, differing mainly in size and shape (species of the latter are larger and less fusiform). The protoconch is rounded in Anna, but tabulate in Parviphos. The terminal varix is massive in Anna, but does not project out from the whorl, whereas in Parphivos it is projected outwards (WatTers 2009). 
There are no records of Parviphos or Anna among the Brazilian buccinids (Аввотт 1972, Rios 1985, 1994, 2009, WatTers 2009). Anna capixaba sp. nov. is known from to the Central South Brazilian coast and it is not closely related to any other buccinid species in this region. However, the only buccinid which is somewhat similar to A. capixaba sp. nov. is D. bernardoi (COSTA \& GOMES 1998) (Figs 7-8), ranging from Salvador (state of Bahia) to Rio de Janeiro. Dianthiphos bernardoi differs especially in the sculpture of the the body, showing uniformly low ribs and flattened spiral threads, whereas A. capixaba sp. nov. has strong ribs and rounded prominent spiral threads. Moreover, A. capixaba sp. nov. also differs from $D$. bernardoi in having more convex whorls.

Anna capixaba sp. nov. is the first species of the Anna found in the Brazilian coast and this new data greatly extends the southern distribution of the genus in the western Atlantic.

\section{ACKNOWLEDGEMENTS}

We thanks to Antonio C. Lyra, from Guarapari, Espírito Santo, for providing the material studied. We also thanks to Koen Fraussen; Luiz R. de Simone, and Rodrigo Salvador from Museu de Zoologia, Universidade de São Paulo (MZSP) for their comments on this paper, and Guilherme Ide and Ricardo Kawada from MZSP for the multifocus photography

\section{LITERATURE CITED}

Аввотт, R.T. 1972. American Seashells. New York, Van NostrandReinhold Company, $2^{\text {nd }}$ ed., 663p.

Costa, P.M.S. \& R.S. Gomes. 1998. A new Species of Pisania Bivona, 1832 (Mollusca, Gastropods, Prosobranchia) to Brazilian coast. Siratus 14: 15-17.
García, E.F. 2008. Four new buccinid species (Gastropoda: Buccinidae) from the western Atlantic. Novapex 9 (4): 141148.

HAYASHI, S. 2005. The molecular phylogeny of the Buccinidae (Caenogastropoda: Neogastropoda) as inferred from complete mitochondrial 16S rRNA gene sequences of selected representatives. Molluscan Research 25 (2): 85-89.

Kos'Yan, A.R. \& Y.I. Kantor. 2007. Morphological phlylogenetic analysis of gastropods from family Buccinidae. Doklay Biological Sciences 415: 270-272.

LANDAU, B. \& G.J. VermeIJ. 2012. The genera Engina and Ameranna nov. gen. (Mollusca: Gastropoda, Buccinoidea, Buccinidae, Pisaniinae) from the western Atlantic Neogene. Cainozoic Research 9 (1): 121-133.

Pope, G.T. \& Y. Goto. 1991. European Seashells. Wiesbaden, Hemmen, vol. 1, 352p.

Rios, E.C. 1985. Seashells of Brasil. Rio Grande, Universidade Federal do Rio Grande, 328p.

Rios, E.C. 1994. Seashells of Brasil. Rio Grande, Universidade Federal do Rio Grande, $2^{\text {nd }}$ ed., 368p.

Rios, E.C. 2009. Compendium of Brazilian Sea Shells. Rio Grande, Evangraf, 668p.

VermeIJ, G.J. 2006. The Cantharus group of pisaniine buccinid gastropods: Review of the Oligocene to Recent genera and description of some new species of Gemophos and Hesperisternia. Cainozoic Research 4: 71-96.

Watters, G.T. 2009. A revision of the Western Atlantic Ocean genera Anna, Antillophos, Bailya, Caducifer, Monostiolum, and Parviphos, with description of new genus, Dianthiphos, and notes on Engina and Hesperisternia (Gastropoda: Buccinidae: Pisaniinae) and Cumia (Colubrariidae). The Nautilus 123 (4): 225-275.

Submitted: 11.VI.2012; Accepted: 14.IX.2012.

Editorial responsibility: Marcos D.S. Tavares 